\section{Brønsted Acid-Catalyzed Dipeptides Functionalization through Azlactones}

\author{
Igor F. dos Santos, Pedro P. de Castro, Angelina M. de Almeida and \\ Giovanni W. Amarante $*$,a
}

Departamento de Química, Universidade Federal de Juiz de Fora, 36036-900 Juiz de Fora-MG, Brazil

\begin{abstract}
Azlactones are useful building blocks in the synthesis of functional amino acid derivatives, heterocycles and bioactive molecules. In this work, a protocol for the organocatalytic functionalization of dipeptides has been presented. 2-Alkyl-substituted azlactone intermediates in the presence of different amines and alcohols were combined in a ring opening reaction approach. The products were synthesized in moderate to excellent isolated yields, providing new insights in peptide transformations involving carbodiimide activation.
\end{abstract}

Keywords: azlactone, Brønsted acid, organocatalysis

\section{Introduction}

The development of efficient reactions for the preparation of functional amino acids and peptides has emerged as an important field in organic chemistry, especially those involving catalytic processes. ${ }^{1-3} \mathrm{In}$ this context, azlactones (also known as oxazolones) are promising substrates, since they basically consist of protected amino acids organized as five-membered rings bearing both electrophilic and pronucleophilic sites in their structure. ${ }^{4,5}$ Due to this versatility, these heterocycles have been extensively employed in a wide scope of transformations, ${ }^{6}$ in particular the preparation of quaternary amino acid derivatives. ${ }^{7-12}$

Different 4-substituted oxazolones are easily available, as this moiety originates from the amino acid precursor $^{13}$ or by hydrogenation of the well-known Erlenmeyer azlactones $^{14}$ (Figure 1). However, substituents at position 2 are in most cases restricted to a phenyl or methyl group.

Besides, the azlactone ring opening reaction by nucleophiles consist of an important way to access bisprotected amino acid derivatives, affording compounds with potential not only in medicinal chemistry, ${ }^{15}$ but also as precursors in total synthesis. ${ }^{16}$ Although our research group has recently investigated the ring opening reactions of 2-phenyl-azlactones in the presence of nucleophiles, ${ }^{17}$ the preparation and reactivity of other 2-substituted oxazolones are still unreported. Herein is reported the functionalization of peptide derivatives achieve through carbodiimide mediated intramolecular cyclization and an organocatalytic azlactone ring opening reactions.

\section{Experimental}

General procedure for the preparation of azlactone rings $2 a$ and $\mathbf{2 b}$

In a flamed screw cap vial and under nitrogen atmosphere and ice bath, $0.2 \mathrm{mmol}$ of a $N$-benzoyldipeptide was added. After, $\mathrm{CH}_{2} \mathrm{Cl}_{2}$ was cannulated at the concentration of $0.2 \mathrm{~mol} \mathrm{~L}^{-1}$ in dipeptide. To this solution, $0.22 \mathrm{mmol}$ (1.1 eq.) of $\mathrm{N}$-(3-dimethylaminopropyl)$N$ '-ethylcarbodiimide hydrochloride (EDC) was added.<smiles>[R]C(=O)NC([R])C(=O)O</smiles>

Figure 1. Azlactone preparation and basic scaffold.<smiles>[R]C1=NC([R])C(=O)O1</smiles>

Azlactone

*e-mail: giovanni.amarante@ufjf.edu.br 
The reaction mixture was kept at $0{ }^{\circ} \mathrm{C}$ and under nitrogen atmosphere for 1 hour. The reaction mixture was then diluted in $10 \mathrm{~mL}$ of $\mathrm{CH}_{2} \mathrm{Cl}_{2}$ and washed 5 times with $5 \mathrm{~mL}$ of distilled water. The organic phase was dried over anhydrous $\mathrm{Na}_{2} \mathrm{SO}_{4}$ and concentrated under reduced pressure, affording the desired azlactones without no need of chromatography column.

General procedure for the catalytic azlactone (2a or $\mathbf{2 b}$ ) ring opening in the presence of amines or alcohols

In a flamed screw cap vial and under nitrogen atmosphere, $0.8 \mathrm{mmol}$ of the nucleophile (amine or alcohol) and $0.02 \mathrm{mmol}(10.0 \mathrm{~mol} \%)$ of (+/-)-camphorsulfonic acid was added. After, $\mathrm{CH}_{2} \mathrm{Cl}_{2}$ was cannulated at the concentration of $0.8 \mathrm{~mol} \mathrm{~L}^{-1}$ in nucleophile. To this solution, was added $0.2 \mathrm{mmol}$ of azlactone $\mathbf{2} \mathbf{a}$ or $\mathbf{2 b}$. The reaction mixture was kept at room temperature and under nitrogen atmosphere for $24 \mathrm{~h}$. The reaction mixture was then concentrated under reduced pressure and purified through silica gel chromatography by using ethyl acetate/hexanes as solvents (up to $50 \%$ ethyl acetate/hexanes). The purified products were then fully characterized by the conventional elemental analysis.

\section{Results and Discussion}

Initially, $N$-benzoyl dipeptides (1a and $\mathbf{1 b}$ ) were prepared in 3 steps according to literature protocols. ${ }^{18} \mathrm{We}$ envisioned that these compounds, in the presence of EDC, could afford a very interesting 2-alkyl-substituted azlactone scaffold. To the best of our knowledge, this consists the first report of isolation of this type of heterocycle derived from a peptide through an azlactone approach. ${ }^{19}$ To our delight, the desired azlactones $\mathbf{2 a}$ and $\mathbf{2} \mathbf{b}$ were successfully synthesized and isolated in good to excellent yields (Scheme 1). ${ }^{1} \mathrm{H}$ nuclear magnetic resonance (NMR) data of compound $\mathbf{2 b}$ showed an unusual ${ }^{5} \mathrm{~J}$ coupling (homoallylic coupling) between alanine $\mathrm{CH}$ hydrogen and glycine $\mathrm{CH}_{2}$ hydrogens, due to the formation of the azlactone $\mathrm{C}=\mathrm{N}$ double bond; this correlation was also observed in $2 \mathrm{D}$ ${ }^{1} \mathrm{H}-{ }^{-1} \mathrm{H}$ COSY (correlation spectroscopy) experiments (see Supplementary Information).
We then decided to react these heterocycles with different nucleophiles, in a ring opening reaction. The initial condition was based in a literature condition for the ring-opening of 2-phenyl-azlactones..$^{17}$ The reaction between azlactone $\mathbf{2 a}$ and octyl alcohol was used as a model to optimize the catalyst loading (Table 1). It was found $10 \mathrm{~mol} \%$ of the (+/-)-camphorsulfonic acid (CSA) catalyst, dichloromethane as solvent for 24 hours, in the presence of the nucleophile as the ideal condition for this transformation. It is also worth mention that no reaction was observed in the absence of the CSA catalyst. $p$ - $\mathrm{TsOH}$ as catalyst gave lower conversion to the product. Moreover, the use of mineral acid such as $\mathrm{HCl} /$ dioxane gave complex mixture of products.

Table 1. Optimization of the catalyst loading for the ring-opening reaction

\begin{tabular}{lc}
\hline CSA catalyst loading & Isolated yield $/ \%$ \\
\hline No catalyst & - \\
$3 \mathrm{~mol} \%$ & 46 \\
$5 \mathrm{~mol} \%$ & 52 \\
$7 \mathrm{~mol} \%$ & 63 \\
$10 \mathrm{~mol} \%$ & 87 \\
$15 \mathrm{~mol} \%$ & 78 \\
\hline
\end{tabular}

asolated yield of compound $\mathbf{3 c}$.

After optimization of the reaction conditions, different amines and alcohols were then evaluated as nucleophiles (Scheme 2). Due to the instability of azlactones $\mathbf{2 a}$ and $\mathbf{2 b}$, the crude reaction was washed with distilled water for 5 times and the dichloromethane was employed in the next reaction without further purification. Therefore, reported yields correspond to the global yields of these two steps.

The reaction was also found to tolerate the use of both azlactones, affording compounds $\mathbf{3 a - 3 \mathbf { i }}$ in moderate to excellent yields (ranging from 61 to $91 \%$ ). Even when employing a sterically bulky alcohol such as isopropanol or a less nucleophilic amine like aniline, the desired products were isolated in 62 and $61 \%$, respectively. Unfortunately, under the optimized reaction conditions tertiary amine or alcohol failed.<smiles>[R]C(NC(=O)c1ccccc1)C(=O)NCC(=O)O</smiles>

$1 \mathrm{a}: \mathrm{R}=i \mathrm{Bu}$ 1b: $R=M e$

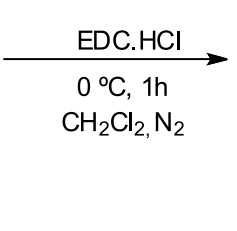


<smiles>[R]C(NC(=O)c1ccccc1)C(=O)NCC(=O)O</smiles><smiles>CCCCOC(=O)CNC(=O)C(CC(C)C)NC(=O)c1ccccc1</smiles>

3a $(69 \%)$<smiles>CCCCCCCCOC(=O)CNC(=O)C(C)NC(=O)c1ccccc1</smiles><smiles>CCCCCCCCOC(=O)CNC(=O)C(CC(C)C)NC(=O)c1ccccc1</smiles><smiles>CC(NC(=O)c1ccccc1)C(=O)NCC(=O)OCc1ccccc1</smiles><smiles>CC(C)CC(NC(=O)c1ccccc1)C(=O)NCC(=O)OC(C)C</smiles>

Scheme 2. Preparation of compounds 3a-3i.

Finally, the catalytic mechanism seems to proceed through azlactone activation at the basic ring nitrogen by the catalyst CSA forming an ion-pairing intermediate that is then susceptible to nucleophilic attack. ${ }^{17}$

\section{Conclusions}

In summary, a protocol for the organocatalytic functionalization of dipeptides has been presented. Different amines and alcohols could be employed under this reaction condition, affording the corresponding products in moderate to excellent yields. Moreover, to the best of our knowledge, this is the first report of isolation of an azlactone intermediate derived from a peptide, providing new insights in the peptide syntheses involving carbodiimide activation.<smiles>CCCCCCCCNC(=O)CNC(=O)C(C)NC(=O)c1ccccc1</smiles><smiles>CCCCCCCCNC(=O)CNC(=O)C(CC(C)C)NC(=O)c1ccccc1</smiles><smiles>CC(C)CC(NC(=O)c1ccccc1)C(=O)NCC(=O)NCc1ccccc1</smiles><smiles>CC(C)CC(NC(=O)c1ccccc1)C(=O)NCC(=O)Nc1ccccc1</smiles>

\section{Supplementary Information}

Copies of HRMS, IR and NMR spectra for the prepared compounds are available free of charge at http://jbcs.sbq.org.br as PDF file.

\section{Acknowledgments}

We are grateful to CAPES, CNPq, FAPEMIG, Rede Mineira de Química and UFJF for financial support.

\section{References}

1. Nájera, C.; Sansano, J. M.; Chem. Rev. 2007, 107, 4584.

2. Luparia, M.; Oliveira, M. T.; Audisio, D.; Frébault, F.; Goddard, R.; Maulide, N.; Angew. Chem. Int. Ed. 2011, 50, 12631.

3. Audisio, D.; Luparia, M.; Oliveira, M. T.; Klütt, D.; Maulide, N.; Angew. Chem. Int. Ed. 2012, 51, 7314. 
4. Melhado, A. D.; Luparia, M.; Toste, F. D.; J. Am. Chem. Soc. 2007, 129, 12638.

5. Melhado, A. D.; Amarante, G. W.; Wang, Z. J.; Luparia, M.; Toste, F. D.; J. Am. Chem. Soc. 2011, 133, 3517.

6. de Castro, P. P.; Carpanez, A. G.; Amarante, G. W.; Chem. Eur. J. 2016, 22, 10294.

7. Weber, M.; Jautze, S.; Frey, W.; Peters, R.; J. Am. Chem. Soc. 2010, 132, 12222.

8. Weber, M.; Frey, W.; Peters, R.; Chem. Eur. J. 2013, 19, 8342.

9. Ávila, E. P.; de Mello, A. C.; Diniz, R.; Amarante, G. W.; Eur. J. Org. Chem. 2013, 1881.

10. Ávila, E. P.; Justo, R. M. S.; Gonçalves, V. P.; Pereira, A. A.; Diniz, R.; Amarante, G. W.; J. Org. Chem. 2015, 80, 590.

11. Zheng, Y.; Deng, L.; Chem. Sci. 2015, 6, 6510.

12. Trost, B. M.; Czabaniuk, L. C.; Chem. Eur. J. 2013, 19, 15210.

13. Weber, M.; Frey, W.; Peters, R.; Adv. Synth. Catal. 2012, 354, 1443.
14. Pinheiro, D. L. J.; Ávila, E. P.; Amarante, G. W.; ChemistrySelect 2016, $1,2960$.

15. Dong, S.; Liu, X.; Zhu, Y.; He, P.; Lin, L.; Feng, X.; J. Am. Chem. Soc. 2013, 135, 10026.

16. Lee, J. W.; Ryu, T. H.; Oh, J. S.; Bae, H. Y.; Jang, H. B.; Song, C. E.; Chem. Commun. 2009, 7224.

17. Pereira, A. A.; de Castro, P. P.; de Mello, A. C.; Ferreira, B. R. V.; Eberlin, M. N.; Amarante, G. W.; Tetrahedron 2014, 70, 3271.

18. de Castro, P. P.; dos Santos, I. F.; Amarante, G. W.; Curr. Org. Synth. 2016, 13, 440.

19. Aljaẑ-Roẑiĉ, M.; Svete, J.; Stanovnik, B.; J. Heterocycl. Chem. 1995, 32, 1605.

Submitted: February 16, 2017 Published online: March 27, 2017 